\title{
PEMBELAJARAN KITAB KUNING DALAM MENANGKAL RADIKALISME
}

\author{
Zahdi Taher \\ Institut Agama Islam Negeri (IAIN) Metro \\ Email: zahdi@metrouniv.ac.id
}

\begin{abstract}
Kitab Kuning is a book that becomes an identity in a learning of Islamic values in a pesantren. Because pesantren is a place for a person to insist on knowledge taught directly by a cleric or religious teacher, as the oldest educational model and learning system in Indonesia. The pesantren has also undergone a transformation due to social change that is developing so fast. The learnig methods are methods to compere in the midst of global currents to counteract the flourishing of radicalism in yhe era of modernization the can affect many generations. The yellow book has existed very much since before independence, precisely in the colonial era, this book has become a means of educating Muslims in the field of religion. Also the role of Pesantren which is at the forefront in preserving the yellow book treasury, which consist of various materials such as figh, monotheism, interpretation, hadith, morals, to sufism, This research uses literature study with a historical approach, which is a method for gathering informaton relevant to the topic or problem thar is the object of research, then brought to the present. This research is expected to be able to add knowlwdge in the study of the yellow book that can give birth to the attitude of tasamuh in every santri.
\end{abstract}

Keywords: Yellow Book, Pesantren, Radicalism

\begin{abstract}
Abstrak
Kitab Kuning adalah buku yang menjadi identitas dalam pembelajaran nilai-nilai Islam di sebuah pesantren. Karena pesantren adalah tempat bagi seseorang untuk menuntut ilmu yang diajarkan langsung oleh seorang ulama atau guru agama, sebagai model pendidikan tertua dan sistem pembelajaran di Indonesia. Pesantren juga telah mengalami transformasi karena perubahan sosial yang berkembang begitu cepat. Metode pembelajaran adalah metode untuk bersaing di tengah arus global untuk menangkal berkembangnya radikalisme di era modernisasi yang dapat mempengaruhi banyak generasi. Buku kuning sudah ada sejak sebelum kemerdekaan, tepatnya di era kolonial, buku ini telah menjadi sarana mendidik umat Islam di bidang agama. Juga peran Pesantren yang berada di garis depan dalam melestarikan perbendaharaan buku kuning, yang terdiri dari berbagai bahan seperti figh, tauhid, interpretasi, hadits, moral, hingga tasawuf. Penelitian ini menggunakan studi literatur dengan pendekatan historis, yang merupakan metode pengumpulan informasi yang relevan dengan topik atau masalah yang menjadi objek penelitian, kemudian dibawa ke masa kini. Penelitian ini diharapkan dapat menambah pengetahuan dalam studi buku kuning yang dapat melahirkan sikap tasamuh di setiap santri.
\end{abstract}

Kata kunci: Buku Kuning, Pesantren, Radikalisme

\section{A. Pendahuluan}

Kitab kuning adalah sebuah alat untuk mencerdaskan anak bangsa melalui pendidikan pesantren. Pesantren adalah model pendidikan tertua di Indonesia. Keberadaan pesantren di penjuru dunia serta sistem-sistem pendidikan yang ada saat ini adalah eksistensi pesantren tidak lapuk digerus 
zaman dengan segala sesuatu perubahan yang ada. Kitab kuning juga merupakan variabel penting yang mempunyai posisi menarik di dalam membedakan muslim tradisionalis dengan modernis. Tradisionalis yaitu kelompok muslim yang identik dengan santri-santri pondok salaf di dalam pesantren yang sangat kuat dengan tradisi kitab kuningnya yang sangat dekat beragam pembelajaran seperti fikih, tauhid, tafsir, hadis, akhlak, dan tasawuf. Sedangkan kelompok modernis terdiri dari ulama atau para pelajar muslim yang tertarik dengan gagasan pemurnian ajaran Islam yang mempunyai konsep purifikasi keagamaan. Perbedaan ini semakin lama semakin terlihat dengan jelas seiring dengan polarisasi dan preferensi politik kedua kelompok ini. Peran Kitab Kuning sangatlah penting didalam bemberantas atau menangkal radikalisme di dalam agama Islam, karena sampai sekarang kitab kuning tersebut masih dipelajari oleh banyak generasi muda muslim terutama bagi para santri yang menuntut ilmu melalui pesantren-pesantren yang ada di Indonesia ini. ${ }^{1}$ Karena Pesantren di sini mempunyai peran yang sangat penting sebagai garda terdepan dalam pelestarian khazanah kitab kuning di bumi Nusantara di dalam menangkal radikalisme ini yang mana sudah mencapai pada taraf yang sangat menghawatirkan. ${ }^{2}$ Kekuasaan kolonial di Jawa ini masih sangatlah kuat, artinya ada banyak persoalan kesejahteraan yang menjadi masalah nyata umat Islam saat itu. Beberapa masalah nyatanya yaitu fakta maraknya radikalisme dan intoleransi yang terjadi di Indonesia, bahwa pelakunya adalah alumni pesantren atau aktivis majelis taklim sehingga pesantren menjadi ciri negatif yang menempel pada diri seseorang karena adanya pengaruh dari lingkungannya atau sebagai pelaku radikalisme. ${ }^{3}$ Pembahasan ini yangat penting untuk dikupas guna mengetahui bagaimana kebenaran dan pembahasannya secara lengkap serta bengetahui apa saja hal-hal terpenting mengenai peran kitab kuning dalam menangkal radikalisme yang ada di Indonesia ini.

\section{B. Pembahasan}

\section{Ruang Lingkup Kitab Kuning}

Kitab kuning adalah kitab klasik yang ada di pesantren-pesantren dimana pola pengajarannya di didik langsung oleh seorang ustad atau kiyai, karena perkataan kiyai atau perbuatannya tidak jarang dijadikan pedoman oleh para santri, dan bahkan bukan hanya santri saja yang menjadikan kiyai sebagai

${ }^{1}$ Ali Muqoddas, "Syeikh Nawawi Al-Bantani Al-Jawi Ilmuan Spesialis Ahli Syarah Kitab Kuning," Tarbawi: Jurnal Pendidikan Islam 11, No. 1 (1 Januari 2014): 2-4, Https://Doi.Org/10.34001/Tarbawi.V11i1.186.

2 Fathur Rohman, "Pendidikan Islam Anti Radikalisme Melalui Nadham (Telaah Kitab Shifa' Al-Ummah Karya Kh. Taufiqul Hakim Bangsri Jepara)," Tadris: Jurnal Pendidikan Islam 13, No. 1 (30 Juni 2018): 2, Https:/ / Doi.Org/10.19105/Tjpi.V13i1.1757.

3 Afwah Mumtazah, "Kajian Multikulturalisme Dalam Kitab Kuning," Jurnal Educationem 1, No. 01 (30 Juni 2019): 1-5. 
panutan, yaitu para masyarakat sekitar juga. ${ }^{4}$ Karena kiyai tidak hanya sekedar membacakan dan menterjemahkan teks saja, tetapi juga memberikan mengenai bagaimana saja pandangan-pandangan (interpretasi) pribadi secara faktual, baik mengenai isi maupun bahasa pada teks tersebut dengan menerjemahkan kata demi kata, kemudian dilengkapi dengan uraian panjang mengenai maksud dari pada kalimat-kalimat tersebut yang disertai contoh-contohnya dalam kehidupan masyarakat dalam pemahaman agama tersebut, dan setelah itu juga akan diberikan oleh ustad penguatan yang harus dimiliki oleh setiap santri yaitu berupa motivasi-motivasi dan semangat untuk menjaga dan menjalankannya. ${ }^{5}$ Yang kemudian menumbuhkan nilai-nilai keagamaan dalam jiwa seorang santri dengan tidak menggunakan cara kekerasan yang dapat menimbulkan kemunculan paham radikalisme dalm diri seorang santri karena adanya pengaruh dari pihak lain. ${ }^{6}$

Mengapa dinamakan kitab kuning karena tulisannya dicetak pada sebuah kertas berwarna kuning sebagai ciri khas dan penamaannya, juga sebagaimana tradisi awal kitab itu dicetak dan dibukukan ditunjukkan bahwa kitab kuning adalah suatu alat atau media pembelajaran adab yang sudah melalui proses serta perubahan-perubahan karena adanya interaksi. Peran kitab kuning dalam pesantren sangatlah strategis. Karena pada umumnya, kitab kuning menjadi pelajaran wajib pesantren dengan beragam tema yang kemudian diterapkan dalam pembelajaran, seperti: fikih, tauhid, tafsir, hadis, tasawuf, nahwu, shorof, dan lain sebagainya. Yang kemudian diajarkan kepada santri secara berurutan, dimulai dari yang paling ringan, sedang, hingga yang secara mendalam. Semangat anti radikalisme yang tidak bisa lepas dari diri seorang santri, masyarakat atau kalangan lainnya. Adapun nilai-nilai dasar yang menjadi keyakinan serta terapan di dalam pesantren yaitu meliputi ajaran Ahl al-Sunnah wal-Jama'ah yang didalamnya mengajarkan tentang prinsip toleransi terhadap sesama, sederhana didalam kehidupan, serta penuh dengan keseibangan dalam hidupnya. Karena dalam dunia pesantren, aspek kemandirian betul-betul ditekankan kepada para santri. Kesehariannya ia lalui hari-harinya dalam sebuah asrama yang terpisah dengan orang tua. Segala macam aktivitas dilakukan secara mandiri didalam pondok pesantren, lengkap dengan perilaku hariannya yang lebih mengajarkan sikap sosial dibandingkan dengan pembelajaran di sekolah umum kepada para santri. Didalam ranah kehidupan di pesantren,

${ }^{4}$ M. Syaifuddien Zuhriy, "Budaya Pesantren Dan Pendidikan Karakter Pada Pondok Pesantren Salaf," Walisongo: Jurnal Penelitian Sosial Keagamaan 19, No. 2 (6 Desember 2011): 15-19, Https://Doi.Org/10.21580/Ws.19.2.159.

5 Abdul Malik, Ajat Sudrajat, Dan Farida Hanum, "Kultur Pendidikan Pesantren Dan Radikalisme," Jurnal Pembangunan Pendidikan: Fondasi Dan Aplikasi 4, No. 2 (2016): 47, Https://Doi.Org/10.21831/Jppfa.V4i2.11279.

6 Ahmad Fawaid, "Survei Bibliografi Kajian Tafsir Dan Fikih Di Pondok Pesantren: Kajian Atas Materi Radikalisme Dalam Literatur Pesantren Dan Respon Kiai Terhadapnya," Proceedings Of Annual Conference For Muslim Scholars, No. Series 1 (22 April 2018), h. 6. 
seorang santri memang sudah dilatih atau digembleng dari sejak dini untuk mandiri, serta saling bekerja sama antar sesama.. Kegiatan harian semisal mempersiapkan makanan dilakukan bersama-sama. Oleh karena itu di era modernisasi seperti ini jangan sampai meninggalkan kajian-kajian yang ada di dalam kitab tersebut, guna terhindar dari gerakan-gerakan radikalisme yang sangat menghawatirkan di era seperti ini. ${ }^{7}$

Kitab kuning menjadi ruh ataupun jiwa pembelajaran pesantren, juga sebagai pemandu pembelajaran sorogan kitab kuning bagi para santri di sebuah pesantren. Pembelajaran sorogan juga dipakai dalam metode ini tujuannya untuk melatih keterampilan santri di dalam mengomunikasikan kajian ataupun kandungan yang terdapat dalam ajaran kitab kuning tersebut. Kitab kuning yang dipilih diantaranya adalah al-Ghoyah wa al-Taqrib untuk santri tahun kedua dan Fathal-Qorib al-Mujib untuk santri tahun ketiga. ${ }^{8}$ Dan menjadi identitas karakteristik pesantren itu sendiri sebagai alat pembelajaran dari sebuah subkultur tersebut. Tanpa adanya kitab kuning, tradisi pengetahuan bangsa di Indonesia tidak akan keluar dari jeratan sufi ataupun fikih ekstrem. ${ }^{9}$ Dengan demikian, kitab kuning ini di dalam pesantren ialah, suatu ajaran yang bisa menjadi landasan atau acuan seorang santri didalam memahami sekaligus merumuskan kembali pemikiran keislaman dalam merespon kemajuan. Keberadaan kitab kuning juga menjadi sangat penting yang harus dipelajari di kalangan santri karena dijadikan sebagai pedoman tata cara beragama, difungsikan sebagai maraji'atau sumber rujukan universal dalam menyikapi segala problem kehidupan. Pesanten dengan identitas keagamaan dipandang eksklusif dan tidak bisa kompromistis untuk melahirkan santri yang anti raikal, anti kekerasan, bermoral, santun dan jujur. ${ }^{10}$

\section{Ruang Lingkup Radikalisme}

Radikalisme yaitu sebuah kata yang berasal dari bahasa latin yang artinya pangkal atau bagian bawah, atau bisa diartikan sebagai tuntutat seseorang dalam menuntut keadilan atau perubahan. Secara terminologi yaitu pandangan paham radikal terhadap politik. Sedangkan radikalisme secara umum yaitu yang sering dikenal sebagai suatu gerakan sosial yang gerakannya mengarah kepada hal-hal yang negatif seperti gerakan radikal atau kekerasan

7 Pradjarta Dirdjosanjoto, Memelihara Umat ; Kiai Pesantren-Kiai Langgar Di Jawa (Lkis Pelangi Aksara, 1997), h. 6-15.

8 Adib Rifqi Setiawan, "Pendidikan Literasi Finansial Melalui Pembelajaran Fiqh Mu'āmalāt Berbasis Kitab Kuning," Nazhruna: Jurnal Pendidikan Islam 3, No. 1 (1 Maret 2020): 2-5, Https://Doi.Org/10.31538/Nzh.V3i1.522.

9 Dian Mohammd Hakim, "Transformasi Kurikulum Pesantren Melalui Metode Pembelajaran Kitab Kuning Dalam Mengembangkan Pesantren : Studi Kasus Di Pondok Pesantren Al-Hikam Malang," Jurnal Andragogi 1, No. 2 (10 Januari 2020), h. 7-9.

10 Mujib Ridlwan, "Dialektika Pesantren Dan Radikalisme Di Pesisir Utara Lamongan," Jurnal Darussalam: Jurnal Pendidikan, Komunikasi Dan Pemikiran Hukum Islam 11, No. 1 (20 September 2019): 6-7, Https://Doi.Org/10.30739/Darussalam.V11i1.448. 
antar individu itu sendiri maupun berkelompok. Gerakan radikalisme ini mempunyai dua level yaitu pemikiran dan tindakan. Level pemikiran itu sendiri adalah suatu rencana yang sedang direncanakan atau difikirkan untuk berjalannya suatu tencana, sedangkan level tindakan yaitu tindakan yang dilaksanakan secara langsung seperti tindak teror yang dilakukan oleh seorang pelaku radikalisme. Kata teror di dalam Kamus Besar Bahasa Indonesia adalah suatu kegiatan ataupun gerakan yang menciptakan ketakutan serta rasa trauma kepada diri seseorang karena adanya kekerasan maupun kekejaman yang dilakukan oleh sang pelaku terorisme tersebut. yang mana gerakan itu akan mereka lakukan secara terus menerus dengan tidak memendang orang disekitarnya baik itu orang tua, anak kecil, serta lainnya guna mencapai tujuan yang mereka inginkan. ${ }^{11}$ Aksi teror ini adalah suatu gerakan yang semakin lama semakin intens yang merupakan masalah ataupun pukulan keras di dalam kalangan umat muslim itu sendiri. ${ }^{12}$ Seperti yang dipersepsikan oleh oleh Lukman Hakim atau wakil kepala LIPI, dalam pengantar buku Islam dan Radikalisme diIndonesia. ${ }^{13}$

Dimana pemberitaan mengenai gerakan radikalisme yang terdapat pada pesantren itu, sudah berlangsung sejak adanya proses perencanaan berita di rapatredaksi sehingga proses penyusunan berita melalui peliputan dan penulisan itu ada pada peristiwa peledakan bom yang terjadi di Pesantren Umar bin Khattab, Bima, Nusa Tenggara Barat yang terjadi tepatnya pada tanggal 11 Juli 2011 yang juga dipertimbangkan pada rapat perencanaan isu majalah GATRA. Majalah Gatra itu memandang bahwa peristiwa yang terjadi itu memiliki nilai berita tinggi, karena berita yang dipertimbangkan untuk isu tersebut di antaranya adalah kehangatan, magnitude, eksklusif, adapun sudutsudut pandang lain yaitu dramatis, dan misi. Sedangkan menurut wakil kepala pusat liputan Gatra Mujib Rahman, peristiwa ini adalah peristiwa yang cukup mengejutkan karena sebuah pesantren di pedalaman Bima, yang tidak pernah menjadi sorotan sebelumnya ternyata diam-diam pengajarnya malah merakit bom.14 Radikalisme disini yaitu suatu paham konspirasi yang didalamnya menganung unsur kekerasan (terorisme) yang bisa dilakukan secara individu maupun berkelompok terhadap seseorang.

Baik yang terdapat didalam lingkungan masyarakat, orang luar, maupun dalam sebuah pesantren. gambaran secara lengkap mengenai pesantren di

11 Fuadi Isnawan, "Program Deradikalisasi Radikalisme Dan Terorisme Melalui Nilai-Nilai Luhur Pancasila," Fikri : Jurnal Kajian Agama, Sosial Dan Budaya 3, No. 1 (31 Juli 2018): 7-8, Https:/ / Doi.Org/10.25217/Jf.V3i1.275.

12 Muh Sya'roni, "Strategi Integrasi Pendidikan Anti Radikalisme Dalam Kurikulum Sma/Ma," Karangan: Jurnal Bidang Kependidikan, Pembelajaran, Dan Pengembangan 1, No. 01 (16 November 2019), h. 2-6.

13 Abdul Halim, "Pendidikan Pesantren Dalam Menghadapi Tantangan Radikalisme," Falasifa: Jurnal Studi Keislaman 8, No. 1 (19 Maret 2017), h. 9-12.

14 Ken Andari, Dadang Rahmat Hidayat, Dan Efi Fadilah, "Konstruksi Majalah Gatra Tentang Radikalisme Di Pesantren," Students E-Journal 1, No. 1 (2012), h. 2-8. 
Indonesia ini adalah baru diperoleh melalui beberapa sumber-sumber Belanda pada abad ke-19. Berdasarkan data penelitian resmi pemerintah Kolonial, pada abad ke-19 terdapat sekitar 15.000 pesantren yang tersebar luas di Jawa dan Madura, dan dengan perkiraan jumlah santri sekitar 230.000 orang yang diperkuat juga dengan catatan perjalanan Snouck Hurgronje, yang juga ada pada abad ke-19 ke berbagai daerah yang ada di Indonesia. Dari catatan perjalanan ini, tergambar dengan jelas bahwa pesantren pada abad ini telah berkembang sedemikian rupa menjadi satu-satunya sarana pendidikan bagi Muslim Indonesia yang sudah ada sejak dahulu. ${ }^{15}$ Radikalisme agama ini muncul karena adanya pendistribusian wewenang yang tidak merata serta pernyataan bahwa pelaku radikalisme adalah alumni pesantren ${ }^{16}$ atau aktivis majelis taklim sehingga pesantren menjadi ciri negatif yang menempel pada diri seseorang karena adanya pengaruh dari lingkungannya atau sebagai pelaku radikalisme. Dan di era keterbukaan seperti sekarang ini, sudah begitu banyak sekali permasalahan yang terjadi, salah satu permasalahan yang terjadi yaitu seperti isu-isu politis mengenai radikalisme Islam yang merupakan tantangan besar bagi pemeluk agama Islam dalam menyikapi dan menjawabnya. Isu radikalisme Islam ini sebenarnya sudah lama mencuat di permukaan wacana internasional karena sudah sejak dahulu permasalahan ini selalu diperbincangkan.

Yang menyebabkan gerakan radikalisme marak dimana-mana sehingga terjadinya konflik atar individu maupun secara berkelompok yang malah itu akan menambah pandangan buruk atau ciri negarif terhadap pesantren itu sendiri. Secara logika agama manapun tentu saja tidak akan mengajarkan untuk melakukan tindakan radikalisme.17 Semua agamabaik muslim ataupun non muslim menginginkan kedamainan baik di dunia maupun akhirat, dan tidak ada ang tidak menginginkan itu. Namun pada kenyataannya sering sekali terjadi ataupun ditemukan kondisi berbeda, yaitu dimana keterlibatan antar sesama muslim dalam gerakan radikal dan juga agama sering terlibat maupun sering dilibatkan di dalam gerakan radikalisme yang dilakukan oleh umat sebagai ajang adu domba antar sesama bagi penyandang dan pemeluk agama tersebut yang kemudian memunculkan tudingan yang menjadikan masalah bahwa agama sebagai penyebab utama yang menjadikan dunia berantakan, serta ciri negatif yang penuh dengan anarkisme. Sampai-sampai ada juga yang mengatakan bahwa agama harus mati, karena agama merupakan penyebab atau dasar dari

15 Rahman Mantu, "Bina-Damai Dalam Komunitas Pesantren: Sebuah Upaya Counter-Radikalisme," Walisongo: Jurnal Penelitian Sosial Keagamaan 23, No. 1 (15 Juni 2015): 4-6, Https://Doi.Org/10.21580/Ws.23.1.227.

16 Tsabita Shabrina Alfanani, "Konstruksi Sosial Komunitas Pesantren Mengenai Isu Radikalisme (Studi Kasus Pada Pesantren Salaf \& Modern Di Kota Malang)," Jurnal Sosiologi Agama 10, no. 2 (20 Juli 2017): 2-7, https://doi.org/10.14421/jsa.2016.102-01.

17 Abu Rokhmad, "Radikalisme Islam Dan Upaya Deradikalisasi Paham Radikal," Walisongo: Jurnal Penelitian Sosial Keagamaan 20, No. 1 (30 Mei 2012): 2-5, Https://Doi.Org/10.21580/Ws.20.1.185. 
munculnya gerakan radikalisme yang melanda dunia, termasuk semua persoalan baik sosial, persoalan ekonomi seta persoalan ekologi.18 Walaupun pada dasarnya semua itu tidak benar, tetapi bagi sebagian orang yang sudah terkena pengaruh negatif dari masyarakat lainnya yang sudah terpengaruh, semua itu adalah sebuah kebenaran, dan tugas kita sebagai umat yang beragama yaitu adalah dengan menumbuhkan raya sosial yang tinggi, memiliki jiwa bersatu, bermoral dan juga menjauhi lah kekerasan menegakkan kebenaran serta mencintai kedamaian. ${ }^{19}$ M. Dawam Raharjo mengemukakan bahwa ada 4 hipotesis yang melatar belakangi berkembangnya Islam radikal di Indonesia, yaitu:

a. Adanya pengaruh gerakan-gerakan radikal yang semuanya itu menginginkan tegaknya syariat Islam di semua bidang kehidupan.

b. Adanya pengaruh perasaan gembira yang berlebihan terhadap demokratisasi di Indonesia, yang biasanya dimaknai sebagai peluang bagi munculnya gerakan Islam radikal yang pada masa Orde Baru.

c. Terjadinya kegagalan di dalam penegakan negara hukum demokratis, sehingganya menimbulkan kembali banyak inspirasi untuk menegakkan syariat Islam, atau sesuatu yang pada dasarnya bertolak belakang dengan sistem hukum demokratis yang sekuler itu sendiri.

d. Adanya kegagalan gerakan dakwah yang raḥmatan lil-alamin, juga yang toleran terhadap keyakinan antar umat beragama yang menerima perbedaan dan sangat bersifat inklusif. Serta berkembangnya gerakan dakwah yang sangat eksklusif serta intoleransi terhadap keragaman yang ada. ${ }^{20}$

\section{Simpulan}

Kitab Kuning ini adalah suatu kitab yang lebih dari 1000 kitab, yang amat banyak sekali karagannya, misal satu imam saja sebagai contoh seperti Imam Nawawi Al-bantani mempunyai tafsir munir 4 jilid, satu orang pun mempunyai kitab sebanyak 115 kitab dan masalah-masalah yang dikaji salah satunya menangkal radikalisme-radikalisme yang ada di Indonesia ini dengan penerapan pembelajaran akhlak dan ilmu tasawuf yang selalu digabungkan. Dan adapun upaya memahami radikalisme dan anti radikalisme di dunia pesantren dengan pendekatan logika dialektik, dialektika radikalisme dan antiradikalisme dalam kehidupan pesantren bergerak pada aras wacana dan praksis. Keduanya saling

18 Angga Natalia, "Faktor-Faktor Penyebab Radikalisme Dalam Beragama (Kajian Sosiologi Terhadap Pluralisme Agama Di Indonesia)," Al-Adyan: Jurnal Studi Lintas Agama 11, No. 1 (2016): 9-12, Https:/ /Doi.Org/10.24042/Ajsla.V11i1.1436.

19 Nanang Hasan Susanto, "Menangkal Radikalisme Atas Nama Agama Melalui Pendidikan Islam Substantif," Nadwa: Jurnal Pendidikan Islam 12, No. 1 (2018), h. 2-6.

20 Thohir Yuli Kusmanto, Moh Fauzi, Dan M. Mukhsin Jamil, "Dialektika Radikalisme Dan Anti Radikalisme Di Pesantren," Walisongo: Jurnal Penelitian Sosial Keagamaan 23, No. 1 (15 Juni 2015): 6-9, Https://Doi.Org/10.21580/Ws.23.1.221. 
terkait sebagai realitas yang seringkali kontradiktif dan saling memperkuat maka tidak bisa keluar dari cara berpikir yang melihat inti segala sesuatu adalah kontradiksi, baik di dalam alam maupun di dalam kehidupan manusia. Oleh karena itu, kontradiksi adalah segala sesiatu atau tindakan yng berpust pada alam. Proposisi tersebut sangat relevan untuk menjelaskan dinamika radikalisme dan anti radikalisme di pesantren maupun oleh masyarakat sekitar pesantren sebagai sesuatu diantara realitas nyata dan tidak nyata. Adapun yang perlu dipraktekkan yaitu berupa nilai-nilai kehidupan di dalam keseharian santri itu sendiri, sehingganya hal tersebut membentuk suatu kebudayaan dan peradaban yang budaya tersebut mempunyai ciri khas tersendiri itulah yang memebedakan tradisi pendidikan pesantren dengan tradisi yang terdapat pada lembaga pendidikan lainnya. Pembelajaran Kitab kuning di dalam pesantren itu bisa menjadi landasan bagi para santri untuk terus menjadikan kitab kuning sebagai acuan di dalam memahami sekaligus usaha respon terhadap kemajuan yang merumuskan kembali pemikiran keislaman. Keberadaan kitab kuning juga menjadi sangat penting yang harus dipelajari di kalangan santri karena dijadikan sebagai pedoman tata cara beragama, difungsikan sebagai maraji'atau sumber rujukan universal dalam menyikapi segala problem kehidupan. Pesanten dengan identitas keagamaan dipandang eksklusif dan tidak bisa kompromistis untuk melahirkan santri yang anti raikal, anti kekerasan, bermoral, santun dan jujur.

\section{Referensi:}

Alfanani, Tsabita Shabrina. “Konstruksi Sosial Komunitas Pesantren Mengenai Isu Radikalisme (Studi Kasus Pada Pesantren Salaf \& Modern Di Kota Malang)." Jurnal Sosiologi Agama 10, No. 2 (20 Juli 2017): 1-24. Https://Doi.Org/10.14421/Jsa.2016.102-01.

Andari, Ken, Dadang Rahmat Hidayat, Dan Efi Fadilah. “Konstruksi Majalah Gatra Tentang Radikalisme Di Pesantren." Students E-Journal 1, No. 1 (2012): 18.

Dirdjosanjoto, Pradjarta. Memelihara Umat; Kiai Pesantren-Kiai Langgar Di Jawa. Lkis Pelangi Aksara, 1997.

Fawaid, Ahmad. "Survei Bibliografi Kajian Tafsir Dan Fikih Di Pondok Pesantren: Kajian Atas Materi Radikalisme Dalam Literatur Pesantren Dan Respon Kiai Terhadapnya." Proceedings Of Annual Conference For Muslim Scholars, No. Series 1 (22 April 2018): 161-72.

Hakim, Dian Mohammd. "Transformasi Kurikulum Pesantren Melalui Metode Pembelajaran Kitab Kuning Dalam Mengembangkan Pesantren : Studi Kasus Di Pondok Pesantren Al-Hikam Malang." Jurnal Andragogi 1, No. 2 (10 Januari 2020): 39-49.

Halim, Abdul. "Pendidikan Pesantren Dalam Menghadapi Tantangan Radikalisme." Falasifa : Jurnal Studi Keislaman 8, No. 1 (19 Maret 2017): 165-78. 
Isnawan, Fuadi. "Program Deradikalisasi Radikalisme Dan Terorisme Melalui Nilai-Nilai Luhur Pancasila." Fikri: Jurnal Kajian Agama, Sosial Dan $\begin{array}{lllllll}\text { Budaya } & 3, & \text { No. } & 1 & \text { (31 Juli } & \text { 2018): } & \text { 1-28. }\end{array}$ Https://Doi.Org/10.25217/Jf.V3i1.275.

Kusmanto, Thohir Yuli, Moh Fauzi, Dan M. Mukhsin Jamil. "Dialektika Radikalisme Dan Anti Radikalisme Di Pesantren." Walisongo: Jurnal Penelitian Sosial Keagamaan 23, No. 1 (15 Juni 2015): 27-50. Https://Doi.Org/10.21580/Ws.23.1.221.

Malik, Abdul, Ajat Sudrajat, Dan Farida Hanum. "Kultur Pendidikan Pesantren Dan Radikalisme." Jurnal Pembangunan Pendidikan: Fondasi Dan $\begin{array}{lllll}\text { Aplikasi } & 4, & \text { No. } & 2 & \text { (2016): }\end{array}$ Https://Doi.Org/10.21831/Jppfa.V4i2.11279.

Mantu, Rahman. “Bina-Damai Dalam Komunitas Pesantren: Sebuah Upaya Counter-Radikalisme." Walisongo: Jurnal Penelitian Sosial Keagamaan 23, No. 1 (15 Juni 2015): 131-50. Https:/ / Doi.Org/10.21580/Ws.23.1.227.

Mumtazah, Afwah. "Kajian Multikulturalisme Dalam Kitab Kuning." Jurnal Educationem 1, No. 01 (30 Juni 2019): 1-18.

Muqoddas, Ali. "Syeikh Nawawi Al-Bantani Al-Jawi Ilmuan Spesialis Ahli Syarah Kitab Kuning." Tarbawi: Jurnal Pendidikan Islam 11, No. 1 (1 Januari 2014). Https:/ / Doi.Org/10.34001/Tarbawi.V11i1.186.

Natalia, Angga. "Faktor-Faktor Penyebab Radikalisme Dalam Beragama (Kajian Sosiologi Terhadap Pluralisme Agama Di Indonesia)." Al-Adyan: Jurnal Studi Lintas Agama 11, No. 1 (2016): 36-56. Https://Doi.Org/10.24042/Ajsla.V11i1.1436.

Ridlwan, Mujib. "Dialektika Pesantren Dan Radikalisme Di Pesisir Utara Lamongan." Jurnal Darussalam: Jurnal Pendidikan, Komunikasi Dan Pemikiran Hukum Islam 11, No. 1 (20 September 2019): 36-55. Https://Doi.Org/10.30739/Darussalam.V11i1.448.

Rohman, Fathur. "Pendidikan Islam Anti Radikalisme Melalui Nadham (Telaah Kitab Shifa' Al-Ummah Karya Kh. Taufiqul Hakim Bangsri Jepara)." Tadris: Jurnal Pendidikan Islam 13, No. 1 (30 Juni 2018): 133-48. Https://Doi.Org/10.19105/Tjpi.V13i1.1757.

Rokhmad, Abu. "Radikalisme Islam Dan Upaya Deradikalisasi Paham Radikal." Walisongo: Jurnal Penelitian Sosial Keagamaan 20, No. 1 (30 Mei 2012): 79-114. Https:/ / Doi.Org/10.21580/Ws.20.1.185.

Setiawan, Adib Rifqi. "Pendidikan Literasi Finansial Melalui Pembelajaran Fiqh Mu'amalat Berbasis Kitab Kuning." Nazhruna: Jurnal Pendidikan Islam 3, No. 1 (1 Maret 2020): 138-59. Https:/ /Doi.Org/10.31538/Nzh.V3i1.522.

Susanto, Nanang Hasan. "Menangkal Radikalisme Atas Nama Agama Melalui Pendidikan Islam Substantif." Nadwa: Jurnal Pendidikan Islam 12, No. 1 (2018): 65-88. 
Sya'roni, Muh. "Strategi Integrasi Pendidikan Anti Radikalisme Dalam Kurikulum Sma/Ma." Karangan: Jurnal Bidang Kependidikan, Pembelajaran, Dan Pengembangan 1, No. 01 (16 November 2019): 37-45.

Zuhriy, M. Syaifuddien. “Budaya Pesantren Dan Pendidikan Karakter Pada Pondok Pesantren Salaf." Walisongo: Jurnal Penelitian Sosial Keagamaan 19, No. 2 (6 Desember 2011): 287-310. Https://Doi.Org/10.21580/Ws.19.2.159. 